\title{
Immune activation in irritable bowel syndrome: from basic to clinic
}

\author{
Mohammad Bashashati
}

Department of Internal Medicine, Texas Tech University Health Sciences Center, El Paso, Texas

\section{RESUMEN}

El síndrome de intestino irritable (SII) es un trastorno funcional intestinal común con una etiología no identificada. La activación de bajo grado del sistema autoinmunitario ha sido considerada la fisiopatología de este trastorno. En los pacientes que lo padecen, las concentraciones de citocinas están alteradas y las células inmunitarias se infiltran en el intestino. Además, en los pacientes con SII se ha observado la activación de estas células inmunitarias y la presencia de alergias alimenticias. Sin embargo, las características del perfil inmunológico de los pacientes con SII pueden ser objeto de debate en la práctica clínica, dado que no existen criterios bien establecidos para diferenciar el SII en controles sanitarios basados en estos parámetros. Esta revisión plantea el rol del sistema inmunitario en la fisiopatología del SII y explora los potenciales roles de estos biomarcadores durante el tratamiento clínico de estos pacientes. (NeuroGastroLatam Rev. 2017;1:116-127)

Corresponding author: Mohammad Bashashati, bashashati.md@gmail.com

Palabras clave: Síndrome de intestino irritable. Inmunología. Mastocito. Linfocitos. Citocinas. 


\section{ABSTRACT}

Irritable bowel syndrome (IBS) is a common functional gastrointestinal disorder with unidentified etiology. Low-grade activation of the immune system has been considered in the pathophysiology of this disorder. The levels of cytokines are altered in these patients and the immune cells infiltrate their intestine. Moreover, activation of the immune cells and features of food allergy are observed in IBS patients. Whether these changes in the immunological profile of IBS patients could be translated to clinical practice is under debate, as there is not clear cut-off for differentiating IBS from healthy controls based on immunological parameters. This review discusses the role of immune system in the pathophysiology of IBS and explores the potential roles of these biomarkers during the clinical management of these patients.

Key words: Irritable bowel syndrome. Immunology. Mast cell. Lymphocyte. Cytokine.

\section{INTRODUCTION}

Irritable bowel syndrome (IBS) is a functional gastrointestinal (GI) disorder of unknown etiology. With a prevalence of $1.1-35 \%$, IBS has one of the highest economic and health burdens among GI diseases ${ }^{1}$.

Conventionally, IBS is considered a disease of brain-gut dysfunction affecting visceral sensation, conception of pain, and secretomotor function of the GI tract. Psychological distress, dysbiosis, GI infection, and female gender are associated with $\mathrm{IBS}^{2,3}$.

Different studies have demonstrated the role of immune system in the development of IBS. Measuring immune signaling molecules such as cytokines and counting the immune cells in the intestine of IBS patients have provided some evidence for the activation of immune system in these patients ${ }^{4-6}$. Studies have demonstrated prominent changes in immune system signaling in IBS in the presence of psychological and central nervous system comorbidities $^{7-9}$. Moreover, changes in the inmune signaling during post-infectious IBS (PI-IBS) support the crucial role of immunie system dysregulation and inflammation in IBS, where there is a shift in the phenotype of circulating immune cells to a $\mathrm{T}$ helper: predominating ${ }^{10}$.

Whether IBS is a disorder within the spetrum of inflammatory bowel disease (IBD) is not proven, as all changes in the immune system of IBS patients are at molecular levels and no gross inflammation is observed in these patients. Disorders such as microscopic colitis ${ }^{11}$, GI mastocytosis, mast cell activation eosinophilic gastroenteritis ${ }^{13}$, celiac disease, and small intestinal bacterial overgrowth manifest with symptoms of IBS, and all share a dysregulated immune system in their pathềphysiology, at least at the level of the GI tract. Studies, mostly in children, have revealed controversial findings about the potential effects of food allergy or intolerance in IBS ${ }^{14}$. It is not clear whether food allergy in IBS is a feature of immune activation. 
The current review: (a) covers literature on the role of immune system, (b) outlines the potential therapeutic and diagnostic approaches through involving the patients' immunological profile, and (c) highlights the future directions of research on the role of immune system in IBS.

\section{Cytokines in IBS}

Cytokines are small protein molecules majorly released by the immune cells. Cytokines regulate differentiation, communications, and interactions between cells. T-cells, macrophages, and mast cells are the major sources of cytokines. Cytokines are also released by the immune cells which reside in the peripheral and central nervous system as well as the enteric neuronal plexus. Cytokines released by the Schwann cells and endothelial cells regulate pain, vascular permeability, and inflammation ${ }^{15}$.

Cytokines include lymphokines and monokines which are produced by lymphocytes and monocytes, respectively. A form of cytokine which has chemotactic activities is called chemokine. Interleukins (ILs) are cytokines which are produced by one leukocyte and act on other leukocytes ${ }^{15}$. Cytokines are divided into pro- and anti-inflammatory from the functional perspectives. Tumor necrosis factor alpha (TNF- $\alpha$ ), interferon- $\gamma$, IL-1, IL-2, IL-6, IL-8, IL-12, IL-17, and IL-18 are pro-inflammatory, while IL-4, IL-10, and transforming growth factor beta (TGF- $\beta$ ) act as anti-inflammatory ${ }^{5,15}$. Table 1 is a summary of major pro- and anti-inflammatory cytokines and their roles as the regulator of the immune system.
Studies on circulating or mucosal cytokine levels in IBS patients versus controls had inconsistent results and were not all methodologically comparable. While some of these studies measured the serum/plasma or mucosal levels/expression (Table 2) ${ }^{17-26}$, otheris have focused on cytokine production by monocyte or lymphocyte supernatants in the presence or absence of stimulators such as lipopolysaccharides (LPSs), 27-30.

Extraintestinal and psychiatric comorbiditiẹs as well as other potential confounders such as dominant symptom and the severity off symptoms have not been sufficiently considered in the design of many of these studies, and the sample sizes are usually small. On top of these, the findings are usually inconsistent between studies. To partially over come this inconsistency, we performed a méta-analysis on serum/plasma cytokine levels in IBS versus controls which indicated that circulating TNF- $\alpha$ tends to be higher in IBS and reaches significance in female IBS på tients and based on IBS subtypes. Circulating IL-10 is significantly lower in male patients with IBS, and colonic IL-10 mRNA has a significantly lower expression in IBS compared to controls in the overall meta-analysis. ${ }^{6}$ In a meta-analysis, we have shown that circulat ing IL-6 levels are significantly increased in IBS compared to controls. This significance was sustained in IBS-D versus controls, while the IL-6 levels were comparable in the other IBS subtypes compared to controls ${ }^{36}$. Based on these findings, the overall picture of cytokine profile in IBS favors a more pro-inflammatory phenotype, although these findings need to be confirmed in larger multicenter studies after adjusting the study subjects based on confounding variables such 
TABLE 1. The functional aspects of pro- and anti-inflammatory cytokines

\begin{tabular}{|c|c|}
\hline Pro-inflammatory & Anti-inflammatory \\
\hline $\begin{array}{l}\text { IFN- } \gamma \text { : increases } \mathrm{MHC}^{\dagger} \text { class I and class II expression and activates } \\
\text { macrophages }\end{array}$ & $\begin{array}{l}\text { IL-4: suppresses macrophage cytotoxicity, antagonizes IFN- } \gamma \text { expression, } \\
\text { stimulates B/T-cell proliferation, and suppresses the development of Th1 } \\
\text { cells }\end{array}$ \\
\hline $\begin{array}{l}\text { IL- } 1 \alpha \text { and IL- } 1 \beta \text { : helps with the differentiation of CD } 4 \text { T-cell, histamine } \\
\text { release from mast cells, and proliferation of mature B-cells, PGE2 } \\
\text { synthesis and increases IL- } 2 \text { expression }\end{array}$ & $\begin{array}{l}\text { IL-10: inhibits IFN- } \gamma \text { production, suppresses Th1 response, and inhibits } \\
\text { synthesis of IL-1 } \beta \text { and NFKB nuclear translocation }\end{array}$ \\
\hline IL-2: activates T-cells, B-cells, and NK cells & IL-11: inhibits pro-inflammatory cytokines and promotes Th2 response \\
\hline $\begin{array}{l}\text { IL-6: stimulates acute phase protein synthesis, and promotes activation } \\
\text { and differentiation of plasma cells and T-cells }\end{array}$ & $\begin{array}{l}\text { IL-13: inhibits inflammatory cytokine production and attenuates the } \\
\text { activation of macrophages }\end{array}$ \\
\hline IL-8: chemoattracts leukocytes & $\begin{array}{l}\text { TGF- } \beta \text { : inhibits monocyte/macrophage MHC class II expression and the } \\
\text { synthesis of pro-inflammatory cytokines }\end{array}$ \\
\hline IL-16: chemoattracts CD4 T Iymphocytes & \\
\hline IL-17: stimulates the expression of IL-6, IL-8, and ICAM ${ }^{\dagger t \dagger}$ & \\
\hline IL-23: activates CD4 memory T-cells and induces IL-17 and IL-6 & \\
\hline $\begin{array}{l}\text { TNF- } \alpha \text { : stimulates PGE2 release as well as acute and chronic } \\
\text { inflammation and induces apoptosis and the release of acute phase } \\
\text { reactant proteins }\end{array}$ & \\
\hline $\begin{array}{l}\text { etrieved and modified from Darkoh et al. } \\
\text { Major histocompatibility complex; } \\
\text { Prostaglandin E2; } \\
{ }^{+} \text {Intercellular adhesion molecule; } \\
\text { NF- } \alpha \text { : tumor necrosis factor alpha; } \\
\text { : interleukins }\end{array}$ & \\
\hline
\end{tabular}

as psychiatric comorbidities, diet, and genetic backgrounds. The absolute cytokine levels in different studies are hugely variable, suggesting that the laboratory methods and kits should also be standardized. Alternatively, these variabilities might be due to population differences ${ }^{31,37}$.

One may argue that changes in cytokines in IBS should be an acquired phenomenon. On the other hand, there are case-control studies on cytokine gene polymorphisms in IBS versus controls, suggesting that these cytokine changes in the IBS patients are somehow driven by a genetic background. A list of studies on cytokine gene polymorphisms in IBS can be found in two published reviews ${ }^{5,38}$. Moreover, Villani et al. ${ }^{39}$ showed that the IL- 6 gene polymorphism is associated with PI-IBS, but at the same time we have to consider that all of these patients were also exposed to a GI infection. Therefore, a combination of acquired and genetic factors may be translated to changes in circulating or mucosal cytokine levels.

The same as studies on cytokine levels, studies on cytokine gene polymorphisms in IBS are not methodologically consistent. As the polymerase chain reaction method for the dẹ tection of single nucleotide polymorphisms (SNPs) is a standardized one and the results are in the form of qualitative variables, the discrepancy may go back to the source populations or potential differences in the selection of cases and controls. We recently performed a meta-analysis on some cytokine gene polymorphisms in IBS. Accordingly, the 
TABLE 2. Selected studies on cytokine levels in patients with irritable bowel syndrome ${ }^{5,31}$

\begin{tabular}{|c|c|c|}
\hline Study & Sample & $\begin{array}{l}\text { Cytokines in IBS versus } \\
\text { control }\end{array}$ \\
\hline Barbaro $^{32}$ & Colon biopsy & IFN- $\gamma \uparrow$ \\
\hline Chang ${ }^{17}$ & Serum & $\begin{array}{l}\text { TNF- } \alpha \rightarrow, \text { IL- } 1 \beta \rightarrow, \text { IL- } 6 \rightarrow \text {, } \\
\text { IL-8 } \rightarrow, \text { IL-12 } \rightarrow, \text { IL-10 } \rightarrow\end{array}$ \\
\hline Darkoh $^{16}$ & Serum & TNF- $\alpha \uparrow$ \\
\hline $\operatorname{Dinan}^{7}$ & Serum & 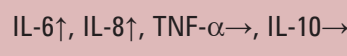 \\
\hline Gwee $e^{\dagger \dagger 33}$ & Colon biopsy & $\mathrm{IL}-1 \beta \uparrow$ \\
\hline Macsharry ${ }^{26}$ & Colon biopsy & $\begin{array}{l}\text { TNF- } \alpha \rightarrow, \text { IL-1 } \beta \downarrow, \text { IL- } 6 \rightarrow, \\
\text { IL- } 8 \downarrow, \text { IL-12 } \rightarrow, \text { TGF- } \beta \downarrow, \text { IL-10 }\end{array}$ \\
\hline Rana $^{22}$ & Serum & TNF- $\alpha \uparrow, I L-6 \uparrow$ \\
\hline Schmulson ${ }^{23}$ & Serum & 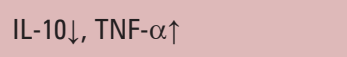 \\
\hline Scully ${ }^{34}$ & Plasma & 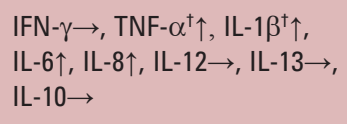 \\
\hline Seyedmirzaee ${ }^{24}$ & Serum & TNF- $\alpha \uparrow, I L-6 \uparrow, I L-8 \uparrow$ \\
\hline Vazquez-Frias 35 & Plasma & TNF- $\alpha \rightarrow$ \\
\hline \multicolumn{3}{|c|}{$\begin{array}{l}\text { No difference } \rightarrow \text {; } \\
\text { increased } \uparrow ; \\
\text { decreased } \downarrow ; \\
\text { N.A: not available; } \\
\text { 'With extraintestinal comorbidities; } \\
\text { "tin post-infectious irritable bowel syndrome; } \\
\text { TNF- } \alpha \text { : tumor necrosis factor alpha; } \\
\text { IL: interleukins }\end{array}$} \\
\hline
\end{tabular}

high producer IL-10 (-1082 G/G) was associated with a decreased odds of IBS. Moreover, carriers of the intermediate producer TGF- $\beta 1$ (+915 G/C) genotype had a tendency toward having less IBS. The analysis of Asian studies revealed an association between the TNF (-308 G/A and G/G) genotypes and IBS38. On the other hand, the meta-analysis of IL-6 (-G174C) polymorphism revealed no differences in the distribution of the studied genotypes or alleles in the IBS compared to controls $^{36}$.

Source population, environmental factors, and methodological/technical variables in the measurement of cytokines may induce variability in the results of original studies. It is also important to mention that as IBS affects the GI tract with a low-grade inflammation at cellular/molecular levels, the scale of immune activation is not sufficient to be detected systemically. Therefore, it is difficult to find a consistent cytokine profile in the blood of heterogeneous IBS patients who are at di ferent phases of the disease and may also have other comorbidities. In summary, while the exact cytokine profile in IBS has not been defined, there is an imbalance favoring pro-inflammatory phenotype.

The studied gene polymorphisms do not nečessarily predict the cytokine profile, suggesting that some of the changes are acquired or mediated by other SNPs which have not been sufficiently studied. Genome-wide associătion studies may help in understanding many of these phenomena. Based on a GWAS study published in 2015, the 7p22.1 locus, which includes the KDEL endoplasmic reticulum protein retention receptor-2 (KDELR2) and glutamate receptor, ionotropic, delta 2 interacting protein (GRID2IP) encoding genes, showed consistent risk effects for IBS and was associated with a trend for increased mucosal KDLER2 mRNA expression. In addition, the rs3917265 in the (IL-1 receptồ type 1) IL1R1 and rs2243250 in the IL-4 genes were associated with IBS as well. The future studies should address whether these findings could be replicated or could be linked with the mRNA expression of the studied genes ${ }^{40}$. To understand the underlying meckanism of the pro-inflammatory phenotype of IBS which is represented by the imbalance of cytokine levels and production, it is crucial to study the potential changes in immune cell counts and function in these patients. 


\section{Immune cells in IBS}

The majority of studies on immune cells in IBS have focused on counting them in intestinal biopsies of patients with IBS and compared them to that of controls. Mast cells and lymphocytes are the major cells which have been counted in IBS patients. Many of these studies are focused on the colon ${ }^{17,41-59}$, while a few studies have counted immune cells in the small bowel ${ }^{56,60-64}$. Table 3 lists some selected studies that have analyzed mast cells and lymphocytes in the colonic mucosa of patients with IBS.

Recently, we conducted a meta-analysis on mast cell and lymphocyte counts in the colonic mucosal layer and lamina propria of IBS patients versus controls ${ }^{67}$. This meta-analysis showed an increased in the mast cells of the rectosigmoid and descending colon of IBS patients. This observation was found both in constipation (IBS-C) and diarrhea (IBS-D) predominant IBS. Based on this meta-analysis, CD3+ T-cells were increased in the rectosigmoid and the descending colon of patients with IBS. CD4+ but not CD8+ T-cells were also increased in the colon of IBS patients.

In addition to studies which counted immune cells in intestinal biopsies of IBS patients, few studies have examined the activation of the immune cells in IBS through looking at their phenotype. Ohman et al. showed that both blood B-cells and T-cells are overactivated in IBS patients. In brief, IBS patients had increased T-cells expressing CD69 and integrin beta7/HLA-DR, while anti-CD3/CD28-stimulated T-cells in blood and colonic tissues from IBS patients proliferated less compared to controls. Moreover, B-cells
TABLE 3. Colonic immune cell counts in irritable bowel syndrome ${ }^{67}$

\begin{tabular}{|c|c|c|}
\hline Study & Counted cells & Region \\
\hline Ahn et al. ${ }^{41}$ & Mast cells; T-cells & $A C, D C, R S$ \\
\hline Akbar et al. ${ }^{42}$ & Mast cells; T-cells & RS \\
\hline Bian et al. ${ }^{65}$ & Mast cells & DC \\
\hline Balestra et al..$^{43}$ & Mast cells & $D C$ \\
\hline Barbara et al. ${ }^{44}$ & Mast cells & $D C$ \\
\hline Barbara et al. ${ }^{45}$ & Mast cells & $D C$ \\
\hline Braak et al. ${ }^{46}$ & Mast cells; T-cells & $A C, D C$ \\
\hline Cenac $^{47}$ & Mast cells & $\mathrm{AC}, \mathrm{RS}$ \\
\hline Chadwick et al. ${ }^{48}$ & Mast cells; T-cells & $A C, D C, R S$ \\
\hline Chang et al. ${ }^{17}$ & Mast cells; T-cells & RS \\
\hline Coeffier et al. ${ }^{49}$ & Mast cells & $D C$ \\
\hline Cremon et al. ${ }^{51}$ & Mast cells & $D C$ \\
\hline Cremon et al. ${ }^{50}$ & Mast cells & $D C$ \\
\hline Dunlop et al. ${ }^{52}$ & Mast cells; T-cells & RS \\
\hline El-Salhy et al..$^{53}$ & Mast cells & $\mathrm{RS}$ \\
\hline Kerckhoffs et al. ${ }^{54}$ & Mast cells & RS \\
\hline $\operatorname{Lee}^{66}$ & Mast cells & RS \\
\hline Ohman et al. ${ }^{59}$ & T-cells & RS \\
\hline 0'Sullivan ${ }^{55}$ & Mast cells & $A C$ \\
\hline Park ${ }^{56}$ & Mast cells & $A C, R S$ \\
\hline Sohn et al. ${ }^{57}$ & Mast cells & RS \\
\hline Sundin et al. ${ }^{58}$ & T-cells & $\mathrm{RS}$ \\
\hline $\begin{array}{l}\text { C: ascending colon; } \\
\text { C: descending colon; } \\
\text { S: rectosigmoid/rectal }\end{array}$ & & \\
\hline
\end{tabular}

isolated from the blood of IBS patients had an increased cell surface expression of immi noglobulin G, CD80, and CD86. The ability of B-cells to increase expression of CD80 in response to LPS was impaired in IBS ${ }^{68,69}$. In a recent study, Rodriguez-Fandino et al. showed that M1-Early cells without LPS stimulation had lower CD11c expression, while the percentage of intermediate (CD$11 \mathrm{c}+\mathrm{CD} 206+\mathrm{CX} 3 \mathrm{CR} 1+)$ cells in cultures without LPS was higher in IBS compared to 
controls suggesting a more advanced maturation phenotype of peripheral blood monocytes/macrophages in IBS patients ${ }^{70}$. Regional mast cell activation has also been shown in IBS. Tryptase, a marker of mast cell activation, is increased in the jejunal fluid of IBS-D patients compared to controls and mast cells spontaneously release more tryptase and histamine in these patients ${ }^{44,61}$.

In summary, immune cell counts are altered in intestinal biopsies of IBS patients. More specifically, mucosal mast cells and lymphocytes are increased in the colon of IBS patients compared to controls. Moreover, blood B-cells and T-cells and intestinal mast cells are overactivated in IBS. In addition, advance maturation of macrophages in IBS patients suggests a functional role for these cells in this disorder. Of note, matured macrophages could be a source for immune signaling molecules such as TNF- $\alpha$ in these patients. ${ }^{70}$ Therefore, there is a very mild form of inflammation in IBS. We need to understand whether this form of inflammation could be translated into non-invasive inflammatory biomarkers such as acute-phase reactants in the blood or stool of IBS patients.

\section{Biomarkers of inflammation}

Whether commercially available biomarkers of inflammation could be used to differentiate IBS from healthy controls is of a great clinical value. This concept has been extensively reviewed by Menees et al. C-reactive protein (CRP), erythrocyte sedimentation rate (ESR), fecal calprotectin, and fecal lactoferrin were 4 biomarkers that were reviewed by these researchers. Increased IL-1 and IL-6 enhances CRP levels through targeting CRP production site, i.e. hepatocytes. As there is an increase in pro-inflammatory cytokines in IBS, increased CRP might be found in these patients as well. ESR also increases through the systematic effects of inflammation on the liver and immune cells. The overproduction of proteins involved in the aggregation of red blood cells increases ESR. Two other markers of intestinal inflammation are lactoferrin and calprotectin which are secreted by activated neutrophils into the feces ${ }^{71}$.

After including 12 studies in their meta-analysis, Menees et al. found no role for CRP, ESR, fecal lactoferrin, and calprotectin in disting guishing IBS from healthy controls; however, CRP $\leq 0.5$ or calprotectin $\leq 40 \mu \mathrm{g} / \mathrm{g}$ could differ entiate IBS from IBD71. The findings of this meta-analysis as well as original studies should be interpreted with caution. The number of iñ cluded studies in this meta-analysis was small for individual biomarker comparisons, and nơ all studies have the 3 comparison groups, i.e. IBS, IBD, and healthy controls. Careful anatysis of Menees et al.'s study ${ }^{71}$ (Figs. 2-5) shows that the predictive probability of being a healthy control or having IBS at different levels do nŏ̀t have a real overlap at least numerically, suggesting that there might be a difference be tween IBS and healthy controls based on these biomarkers. All these biomarkers in differentiating IBS patients from healthy people should be compared in larger well-controlled studies.

Some studies have evaluated the role ôf high-sensitive (HS) CRP as a marker of inflammation in IBS. These studies indicated that HS-CRP is higher in IBS patients compared to healthy controls and these levels were highest in IBS-D and in those patients 
with greater IBS severity ${ }^{72,73}$. These findings also need to be confirmed in larger studies. Based on the latest publication ${ }^{73}$, the median HS-CRP levels in the IBS group and healthy controls were 1.80 and $1.20 \mathrm{mg} / \mathrm{L}$, respectively, with large interquartile ranges questioning the clinical value of HS-CRP in differentiating IBS from healthy controls.

While immune biomarkers might be helpful in differentiating IBS from diseases like IBD which have a much visible pathology and a pro-inflammatory profile, the future studies should focus on finding potential immune-based biomarkers including acutephase reactants of IBS which may help us with the diagnosis of this functional GI disorder as well as the prediction of response to anti-inflammatory therapies.

\section{Food allergy in IBS patients}

Non-celiac gluten sensitivity (NCGS) is a disease which presents with IBS-like symptoms. Furthermore, there has been an increasing interest in gluten-free and low fermentable oligo-di-mono-saccharides and polyols diets in treating IBS patients ${ }^{14,74}$. Whether these food sensitivities are mediated by the immune system is still under debate. Food antigens may activate mast cells; however, skin tests for food allergy are not sufficiently sensitive and may give negative results despite the therapeutic value of eliminating specific food elements from the diet in IBS patients ${ }^{74}$. Direct administration of diluted food antigens into the duodenal mucosa increases intraepithelial lymphocytes in some IBS patients $^{75}$. Moreover, in vitro exposure of the basophils to dietary proteins may or may not activate these immune cells ${ }^{75,76}$. More studies are needed to confirm the role of food allergy and concomitant immune activation in IBS.

\section{Anti-inflammatory medications for IBS}

By considering IBS, a disorder with low-grade inflammation, it would be crucial to examine whether anti-inflammatory medications are helpful in this condition.

In a pilot randomized, double-blind, placềbo-controlled study, mesalazine $(800 \mathrm{mg}$, 3 times daily for 8 weeks) significantly rêduced colonic mast cell infiltration in IBS and increased patients general well-being but had no substantial effects on IBS sympitoms ${ }^{77}$. The same group extended their study through conducting a phase 3 multicentre trial with the same dose of mesalazine but for 12 weeks. With a total of 185 IBS patients included, this study showed that mesalazine was not superior to placebo in relieving abdominal pain/discomfort for at least 50\% gू gै the weeks of the treatment period. However, when the authors considered affirmative añ swers to the question "Did you have satisfaetory relief of your abdominal discomfort ör pain during the last week?" within $\geq 75 \%$ öf the treatment time as "positive response" mesalazine was reported as being helpful in IBS $^{78}$. Another randomized clinical trial with mesalazine ( $2 \mathrm{~g}$ twice daily for 12 weeks) in 136 IBS-D patients showed no improvement of abdominal pain, stool consistency/frequency, or percentage of patients with satisfactory relief of IBS symptoms ${ }^{79}$. In a study by Andrews et al., 8 of 14 IBS patients had a satisfactory response to mesalazine with 
substantial decrease in days with discomfort or disturbed bowel movement ${ }^{80}$. Studies on mesalazine in PI-IBS are underpowered and controversial. While some of them show it is effective ${ }^{79,81}$, others have shown no substantial improvement in the global symptoms or quality of life with mesalazine in these patients $^{82}$.

Based on a randomized, double-blind, placebo-controlled trial on 29 PI-IBS patients with prednisolone (30 mg/day), lamina propria T-lymphocytes significantly decreased after prednisolone; however, no significant improvement in symptoms including abdominal pain, diarrhea, stool frequency, and urgency was observed ${ }^{83}$.

Increased mast cells in IBS may be associated with higher histamine release in IBS patients. Therefore, antihistamines or mast cell stabilizers could be beneficial in IBS. Cromolyn sodium appears to be antidiarrheal in IBS ${ }^{84-86}$. Another study showed that cromolyn sodium decreases abdominal pain in IBS without affecting the bowel movements ${ }^{87}$. Based on another study, the mast cell-stabilizer ketotifen decreased abdominal pain and improved the quality of life of the IBS patients ${ }^{88}$. Moreover, the histamine 1 (H1)-receptor blocker ebastine decreases abdominal pain scores and improves symptom in IBS $^{89}$.

Therefore, the body of literature does not always support anti-inflammatory and anti-allergic medications as potential therapies for IBS. The number of studies and their sample size are small. Categorizing the data based on IBS-subtypes, comorbidities, presence of PI-IBS, and immunological profiles such as intestinal immune cell counts or blood/ mucosal cytokine levels would change this conclusion.

\section{CONCLUSIONS AND FUTURE DIRECTIONS}

Cytokines are imbalanced favoring mostly pro-inflammatory profile in IBS. Intestină mast cell and lymphocyte counts are modestly increased in IBS supporting a low-grade inflammation in these patients. All these changes are not substantial, and there is a ways an overlap in the cytokine profile or intestinal immune cell counts of IBS patients and their healthy controls. Therefore, a clear cutoff limit could not be easily defined fơr any of these parameters. This overlap coula be eliminated by categorizing IBS patients based on the bowel habit subtypes, comorbidities, diet, gender, genotype, or other coñ founding factors such as the presence of previous enteric infection (i.e. PI-IBS). Stres, depression, and psychiatric comorbiditiès are common in IBS and are linked with the immunological profile of these patients. Therefore, neuroimmune interaction should always be considered when interpreting the results of studies on immunological profite of IBS. The concept of PI-IBS is very important and may substantially be linked with changes in the immunological profile of IBS patients. As discussed, the immunologicầ changes of IBS are not just limited to IBS-D and should also be studied in other IBS sulbtypes.

With regard to the acute phase proteins and the biomarkers of inflammation in IBS, there are no sufficient data to support any of them in differentiating IBS from healthy controls. 
The future studies on the immunological profile of IBS patients should appropriately exclude patients with diseases such as microscopic colitis, NCGS, or intestinal mastocytosis. The controls should appropriately represent the healthy population and match with the cases. What recommended for the future is categorizing IBS patients based on parameters such as cytokine, mast cells, or hsCRP levels. By considering a right diagnostic immunology panel, a new diagnosis such as "low-grade inflammatory IBS" should be considered for patients who fulfil the diagnostic criteria of IBS.

The value of subcategorizing IBS patients based on their immunological profile would be more important when anti-inflammatory medications are considered as a treatment option in these patients. Overall, no promising response to medications such as mesalamine could be based on combining data of low-grade inflammatory with non-inflamed IBS patients. A potential hypothesis which should be tested is whether patients with low-grade inflammatory IBS have a better response to anti-inflammatory medications compared to IBS patients without inflammation.

Finally, the field of immune system activation in IBS is not conclusive at this step. Larger studies conducted by an international consortium would help to answer many unknown questions in the field.

\section{REFERENCES}

1. Sperber AD, Dumitrascu D, Fukudo S, et al. The global prevalence of IBS in adults remains elusive due to the heterogeneity of studies: a Rome foundation working team literature review. Gut PLoS One. 2016;9:e93144.
2. Ohman L, Simren M. Pathogenesis of IBS: role of inflammation, immunity and neuroimmune interactions. Nat Rev Gastroenterol Hepatol. 2010 7:163-73.

3. Mayer EA, Labus JS, Tillisch K, Cole SW, Baldi P. Towards a systems view of IBS. Nat Rev Gastroenterol Hepatol. 2015;12:592-605.

4. Barbara G, Cremon C, Carini G, et al. The immune system in irritable bowel syndrome. J Neurogastroenterol Motil. 2011;17:349-59.

5. Bashashati M, Rezaei N, Andrews CN, et al. Cytokines and irritable bowel syndrome: where do we stand? Cytokine. 2012;57:201-9.

6. Bashashati M, Rezaei N, Shafieyoun A, et al. Cytokine imbalance in irritable bowel syndrome: a systematic review and meta-analysis. Neurogastroenterol Motil. 2014;26:1036-48.

7. Dinan TG, Quigley EM, Ahmed SM, et al. Hypothalamic-pituitary-gut axis dysregulation in irritable bowel syndrome: plasma cytokines as a potential biomarker? Gastroenterology. 2006;130:304-11.

8. Gao J. Correlation between anxiety-depression status and cytokines in diarrhea-predominant irritable bowel syndrome. Exp Ther Med. 2013;6:93-6.

9. Liebregts T, Adam B, Bredack C, et al. Immune activation in patients with irritable bowel syndrome. Gastroenterology. 2007;132:913-20.

10. Hughes PA, Brierley SM, Blackshaw LA. Post-inflammatory modificatięn of colonic afferent mechanosensitivity. Clin Exp Pharmacol Physiöl. 2009;36:1034-40.

11. Lazenby AJ, Yardley JH, Giardiello FM, Jessurun J, Bayless TM. Lymphocytic ("microscopic") colitis: a comparative histopathologic study with particular reference to collagenous colitis. Hum Pathol. 1989;20:18-28.

12. Siddiqui AA, Miner PB Jr. The role of mast cells in common gastrointestina diseases. Curr Allergy Asthma Rep. 2004;4:47-54.

13. Talley NJ. Gut eosinophilia in food allergy and systemic and autoimmựe diseases. Gastroenterol Clin North Am. 2008;37:307-32, v.

14. Caffarelli C, Mauro DD, Garrubba M, Mastrorilli C. Allergy in children with functional constipation and irritable bowel syndrome. Iran J Pediatr. 2016;26:e5206.

15. Zhang JM, An J. Cytokines, inflammation, and pain. Int Anesthesiol Clin 2007;45:27-37.

16. Darkoh C, Comer L, Zewdie G, Harold S, Snyder N, Dupont HL. Chemótactic chemokines are important in the pathogenesis of irritable bowel syndrome. PLoS One. 2014;9:e93144.

17. Chang L, Adeyemo M, Karagiannides I, et al. Serum and colonic mucosal immune markers in irritable bowel syndrome. Am J Gastroenteröl. 2012;107:262-72.

18. Chen J, Zhang Y, Deng Z. Imbalanced shift of cytokine expression between T Helper 1 and T Helper 2 (Th1/Th2) in intestinal mucosa of patients with post-infectious irritable bowel syndrome. BMC Gastroenterol. 2012;12,9还.

19. Dinan TG, Cryan J, Shanahan F, Keeling PW, Quigley EM. IBS: an epigènetic perspective. Nat Rev Gastroenterol Hepatol. 2010;7:465-71.

20. Goral V, Kucukoner M, Buyukbayram H. Mast cells count and serum cytokine levels in patients with irritable bowel syndrome. Hepatogastroenterology. 2010;57:751-4

21. McKernan DP, Gaszner G, Quigley EM, Cryan JF, Dinan TG. Altered peripheral toll-like receptor responses in the irritable bowel syndrome. Aliment Pharmacol Ther. 2011;33:1045-52.

22. Rana SV, Sharma S, Sinha SK, Parsad KK, Malik A, Singh K. Pro-inflamma tory and anti-inflammatory cytokine response in diarrhoea-predominant irritable bowel syndrome patients. Trop Gastroenterol Off J Dig Dis Fouñd. 2012;33:251-6.

23. Schmulson M, Pulido-London D, Rodriguez O, et al. Lower serum IL-10 is an independent predictor of IBS among volunteers in Mexico. Am J Gastroenterol. 2012;107:747-53.

24. Seyedmirzaee S, Hayatbakhsh MM, Ahmadi B, et al. Serum immune biomarkers in irritable bowel syndrome. Clin Res Hepatol Gastroenterol. 2016;40:631-7.

25. Bennet SM, Polster A, Törnblom H, et al. Global cytokine profiles and association with clinical characteristics in patients with irritable bowel syndrome. Am J Gastroenterol. 2016;111:1165-76. 
26. Macsharry J, O'Mahony L, Fanning A, et al. Mucosal cytokine imbalance in irritable bowel syndrome. Scand J Gastroenterol. 2008;43:1467-76.

27. Kindt S, Van Oudenhove L, Broekaert D, et al. Immune dysfunction in patients with functional gastrointestinal disorders. Neurogastroenterol Motil. 2009;21:389-98.

28. Hughes PA, Harrington AM, Castro J, et al. Sensory neuro-immune interactions differ between irritable bowel syndrome subtypes. Gut. 2013;62:1456-65.

29. Elsenbruch S, Holtmann G, Oezcan D, et al. Are there alterations of neuroendocrine and cellular immune responses to nutrients in women with irritable bowel syndrome? Am J Gastroenterol. 2004;99:703-10.

30. O'Mahony L, McCarthy J, Kelly P, et al. Lactobacillus and bifidobacterium in irritable bowel syndrome: symptom responses and relationship to cytokine profiles. Gastroenterology. 2005;128:541-51.

31. Bashashati M, Schmulson MJ. From gene polymorphisms to serum cytokine levels in irritable bowel syndrome. Clin Res Hepatol Gastroenterol. 2016;40:525-7

32. Barbaro MR, Di Sabatino A, Cremon C, et al. Interferon-? is increased in the gut of patients with irritable bowel syndrome and modulates serotonin metabolism. Am J Physiol Gastrointest Liver Physiol. 2016;310:G439-47.

33. Gwee KA, Collins SM, Read NW, et al. Increased rectal mucosal expression of interleukin 1 beta in recently acquired post-infectious irritable bowel syndrome. Gut. 2003;52:523-6.

34. Scully P, McKernan DP, Keohane J, et al. Plasma cytokine profiles in females with irritable bowel syndrome and extra-intestinal co-morbidity. Am J Gastroenterol. 2010;105:2235-43.

35. Vazquez-Frias R, Gutierrez-Reyes G, Urban-Reyes M, et al. Proinflammatory and anti-inflammatory cytokine profile in pediatric patients with irritable bowel syndrome. Rev Gastroenterol Mex. 2015;80:6-12.

36. Bashashati M, Moradi M, Sarosiek I. Interleukin-6 in irritable bowel syndrome: A systematic review and meta-analysis of IL-6 (-G174C) and circulating IL-6 levels. Cytokine. 2017;99:132-8.

37. Schmulson M, Saps M, Bashashati M. Abnormal immune regulation in children with irritable bowel syndrome. Rev Gastroenterol Mex. 2015;80:3-5.

38. Bashashati M, Rezaei N, Bashashati $\mathrm{H}$, et al. Cytokine gene polymorphisms are associated with irritable bowel syndrome: a systematic review and meta-analysis. Neurogastroenterol Motil. 2012;24:e1102-566.

39. Villani AC, Lemire M, Thabane M, et al. Genetic risk factors for post-infectious irritable bowel syndrome following a waterborne outbreak of gastroenteritis. Gastroenterology. 2010;138:1502-13.

40. Ek WE, Reznichenko A, Ripke S, et al. Exploring the genetics of irritable bowel syndrome: a GWA study in the general population and replication in multinational case-control cohorts. Gut. 2015;64:1774-82.

41. Ahn JY, Lee KH, Choi CH, et al. Colonic mucosal immune activity in irritable bowel syndrome: comparison with healthy controls and patients with ulcerative colitis. Dig Dis Sci. 2014;59:1001-11.

42. Akbar A, Yiangou Y, Facer P, Walters JR, Anand P, Ghosh S. Increased capsaicin receptor TRPV1-expressing sensory fibres in irritable bowel syndrome and their correlation with abdominal pain. Gut. 2008;57:923-9.

43. Balestra B, Vicini R, Cremon C, et al. Colonic mucosal mediators from patients with irritable bowel syndrome excite enteric cholinergic motor neurons. Neurogastroenterol Motil. 2012;24:e1118-570.

44. Barbara G, Stanghellini V, De Giorgio R, et al. Activated mast cells in proximity to colonic nerves correlate with abdominal pain in irritable bowel syndrome. Gastroenterology. 2004;126:693-702.

45. Barbara G, Wang B, Stanghellini V, et al. Mast cell-dependent excitation of visceral-nociceptive sensory neurons in irritable bowel syndrome. Gastroenterology. 2007;132:26-37.

46. Braak B, Klooker TK, Wouters MM, et al. Mucosal immune cell numbers and visceral sensitivity in patients with irritable bowel syndrome: is there any relationship? Am J Gastroenterol. 2012;107:715-26.

47. Cenac N, Andrews CN, Holzhausen M, et al. Role for protease activity in visceral pain in irritable bowel syndrome. J Clin Invest. 2007;117:636-47.

48. Chadwick VS, Chen W, Shu D, et al. Activation of the mucosal immune system in irritable bowel syndrome. Gastroenterology. 2002;122:1778-83.
49. Coëffier M, Gloro R, Boukhettala N, et al. Increased proteasome-mediated degradation of occludin in irritable bowel syndrome. Am J Gastroenterol. 2010;105:1181-8.

50. Cremon C, Carini G, Wang B, et al. Intestinal serotonin release, sensory neuron activation, and abdominal pain in irritable bowel syndrome. Am J Gastroenterol. 2011;106:1290-8.

51. Cremon C, Gargano L, Morselli-Labate AM, et al. Mucosal immune activa tion in irritable bowel syndrome: gender-dependence and association with digestive symptoms. Am J Gastroenterol. 2009;104:392-400.

52. Dunlop SP, Jenkins D, Spiller RC. Distinctive clinical, psychological, añd histological features of postinfective irritable bowel syndrome. Am J Găstroenterol. 2003;98:1578-83.

53. El-Salhy M, Gundersen D, Hatlebakk JG, Hausken T. Low-grade inflamma tion in the rectum of patients with sporadic irritable bowel syndrome. Mol Med Rep. 2013;7:1081-5.

54. Kerckhoffs AP, ter Linde JJ, Akkermans LM, Samsom M. SERT and TPHmRNA expression are reduced in irritable bowel syndrome patients regardless of visceral sensitivity state in large intestine. Am J Physiol Gastrointes Liver Physiol. 2012;302:G1053-60.

55. O'Sullivan M, Clayton N, Breslin NP, et al. Increased mast cells in the irritable bowel syndrome. Neurogastroenterol Motil. 2000;12:449-57.

56. Park JH, Rhee PL, Kim HS, et al. Mucosal mast cell counts correlate with visceral hypersensitivity in patients with diarrhea predominant irritable bowel syndrome. J Gastroenterol Hepatol. 2006;21:71-8.

57. Sohn W, Lee OY, Lee SP, et al. Mast cell number, substance $P$ and vasoactive intestinal peptide in irritable bowel syndrome with diarrhea. Scand J Gas troenterol. 2014;49:43-51.

58. Sundin J, Rangel I, Kumawat AK, Hultgren-Hörnquist E, Brummer $\frac{\tilde{N}}{\mathrm{~N}} \mathrm{~J}$. Aberrant mucosal lymphocyte number and subsets in the colon of post-înfectious irritable bowel syndrome patients. Scand J Gastroenterêl. 2014;49:1068-75.

59. Ohman L, Isaksson S, Lundgren A, Simrén M, Sjövall H. A controlled stud y of colonic immune activity and beta7+ blood $\mathrm{T}$ lymphocytes in patients with irritable bowel syndrome. Clin Gastroenterol Hepatol. 2005;3:980-6.

60. Foley S, Garsed K, Singh G, et al. Impaired uptake of serotonin by platelet from patients with irritable bowel syndrome correlates with duodenal immune activation. Gastroenterology. 2011;140:e1.1434-43.

61. Guilarte M, Santos J, de Torres I, et al. Diarrhoea-predominant IBS patients show mast cell activation and hyperplasia in the jejunum. Gut. 2007;56:203-9.

62. Martinez C, Lobo B, Pigrau M, et al. Diarrhoea-predominant irritable bowel syndrome: an organic disorder with structural abnormalities in the jejunal epithelial barrier. Gut. 2013;62:1160-8.

63. Martínez C, Vicario M, Ramos L, et al. The jejunum of diarrhea-predominant irritable bowel syndrome shows molecular alterations in the tight junction signaling pathway that are associated with mucosal pathobiology and clinical manifestations. Am J Gastroenterol. 2012;107:736-46.

64. Weston AP, Biddle WL, Bhatia PS, Miner PB Jr. Terminal ileal mucosal mas cells in irritable bowel syndrome. Dig Dis Sci. 1993;38:1590-5.

65. Bian ZX, Li Z, Huang ZX, et al. Unbalanced expression of protease-activăted receptors- 1 and -2 in the colon of diarrhea-predominant irritable bowiel syndrome patients. J Gastroenterol. 2009;44:666-74.

66. Lee H, Park JH, Park DI, et al. Mucosal mast cell count is associated wîth intestinal permeability in patients with diarrhea predominant irritable bowel syndrome. J Neurogastroenterol Motil. 2013;19:244-50.

67. Bashashati M, Moossavi S, Cremon C, et al. Colonic immune cells in iṛ̂i table bowel syndrome: A systematic review and meta-analysis. Neurogâstroenterol Motil. 2017 Aug 29. doi: 10.1111/nmo.13192.

68. Ohman L, Isaksson S, Lindmark AC, et al. T-cell activation in patients with irritable bowel syndrome. Am J Gastroenterol. 2009;104:1205-12.

69. Ohman L, Lindmark AC, Isaksson S, et al. B-cell activation in patients with irritable bowel syndrome (IBS). Neurogastroenterol Motil. 2009;21:644-50, e27.

70. Rodríguez-Fandiño OA, Hernández-Ruiz J, López-Vidal Y, et al. Maturation phenotype of peripheral blood monocyte/macrophage after stimulation 
with lipopolysaccharides in irritable bowel syndrome. J Neurogastroenterol Motil. 2017;23:281-8.

71. Menees SB, Powell C, Kurlander J, Goel A, Chey WD. A meta-analysis of the utility of C-reactive protein, erythrocyte sedimentation rate, fecal calprotectin, and fecal lactoferrin to exclude inflammatory bowel disease in adults with IBS. Am J Gastroenterol. 2015;110:444-54.

72. Hod K, Dickman R, Sperber A, et al. Assessment of high-sensitivity CRP as a marker of micro-inflammation in irritable bowel syndrome. Neurogastroenterol Motil. 2011;23:1105-10.

73. Hod K, Ringel-Kulka T, Martin CF, Maharshak N, Ringel Y. High-sensitive C-reactive protein as a marker for inflammation in irritable Bowel syndrome. J Clin Gastroenterol. 2016;50:227-32.

74. De Giorgio R, Volta U, Gibson PR. Sensitivity to wheat, gluten and FODMAPs in IBS: facts or fiction? Gut. 2016;65:169-78.

75. Fritscher-Ravens A, Schuppan D, Ellrichmann M, et al. Confocal endomicroscopy shows food-associated changes in the intestinal mucosa of patients with irritable bowel syndrome. Gastroenterology. 2014;147:E41012-20.

76. Bucci C, Zingone F, Russo I, et al. Gliadin does not induce mucosal inflammation or basophil activation in patients with nonceliac gluten sensitivity. Clin Gastroenterol Hepatol. 2013;11:e1.1294-9.

77. Corinaldesi R, Stanghellini V, Cremon C, et al. Effect of mesalazine on mucosal immune biomarkers in irritable bowel syndrome: a randomized controlled proof-of-concept study. Aliment Pharmacol Ther. 2009;30:245-52.

78. Barbara G, Cremon C, Annese V, et al. Randomised controlled trial of mesalazine in IBS. Gut. 2016;65:82-90.

79. Lam C, Tan W, Leighton M, et al. A mechanistic multicentre, parallel group, randomised placebo-controlled trial of mesalazine for the treatment of IBS with diarrhoea (IBS-D). Gut. 2016;65:91-9.

80. Andrews CN, Griffiths TA, Kaufman J, Vergnolle N, Surette MG, Rioux KP. Mesalazine (5-aminosalicylic acid) alters faecal bacterial profiles, but not mucosal proteolytic activity in diarrhoea-predominant irritable bowel syndrome. Aliment Pharmacol Ther. 2011;34:374-83.

81. Bafutto M, Almeida JR, Leite NV, Oliveira EC, Gabriel-Neto S, RezendeFilho J. Treatment of postinfectious irritable bowel syndrome and noninfective irritable bowel syndrome with mesalazine. Arq Gastroenterol. 2011;48:36-40.

82. Tuteja AK, Fang JC, Al-Suqi M, Stoddard GJ, Hale DC. Double-blind placebo-controlled study of mesalamine in post-infective irritable bowel syndrome-a pilot study. Scand J Gastroenterol. 2012;47:1159-64.

83. Dunlop SP, Jenkins D, Neal KR, et al. Randomized, double-blind, placebo controlled trial of prednisolone in post-infectious irritable bowel syndrome. Aliment Pharmacol Ther. 2003;18:77-84.

84. Stefanini GF, Prati E, Albini MC, et al. Oral disodium cromoglycate treăt ment on irritable bowel syndrome: an open study on 101 subjects with diarrheic type. Am J Gastroenterol. 1992;87:55-7.

85. Stefanini GF, Saggioro A, Alvisi V, et al. Oral cromolyn sodium in comparison with elimination diet in the irritable bowel syndrome, diarrheic ty $\mathrm{Be}$. Multicenter study of 428 patients. Scand J Gastroenterol. 1995;30:535-41

86. Bolin TD. Use of oral sodium cromoglycate in persistent diarrhoea. Gप̈t. 1980;21:848-50.

87. Daryani NE, Hashemian F, Afkham M, et al. Mast cell stabilizers ass a potential treatment for Irritable bowel syndrome: a randomized placebocontrolled clinical trial. DARU J Pharm Sci. 2015;17:72-8.

88. Klooker TK, Braak B, Koopman KE, et al. The mast cell stabiliser ketotifen decreases visceral hypersensitivity and improves intestinal symptoms patients with irritable bowel syndrome. Gut. 2010;59:1213-21.

89. Wouters MM, Balemans D, Van Wanrooy S, et al. Histamine recepto H1-mediated sensitization of TRPV1 mediates visceral hypersensitivity and symptoms in patients with irritable bowel syndrome. Gastroenterology. 2016;150:875-87.e9. 